\title{
Pragmatic Language Development and Correlation with Vocabulary Ability of 4- to 10-Year-Old Typically Developing Korean Children using Audio-Visual Discourse Tasks
}

\author{
Seungha Song, Young Tae Kim, Soojung Lee, Jung A Kim \\ Department of Communication Disorders, Ewha Womans University, Seoul, Korea
}

Correspondence: Young Tae Kim, PhD Department of Communication Disorders, Ewha Womans University, 52 Ewhayeodae-gil, Seodaemun-gu, Seoul 03760, Korea Tel: $+82-2-3277-2120$

Fax: +82-2-3277-2122

E-mail: youngtae@ewha.ac.kr

Received: January 5, 2017

Revised: February 16, 2017

Accepted: March 8, 2017

This work was supported by the Ministry of Education of the Republic of Korea and the National Research Foundation of Korea (NRF2015S1A5A2A01009816)

\begin{abstract}
Objectives: The field of pragmatics studies language use, which is parallel to structural language such as phonology and grammar. Pragmatic language is considered difficult to assess in a standardized way, because of its variability depending on context. Likewise, the number of studies on pragmatic language development is relatively small compared to other areas, and Korean researchers are often dependent on the results of foreign studies. Methods: Forty-one children participated in this study, divided into three age groups: preschool (4-6 years), elementary school (7-8 years), and middle school (9-10 years). The Korean Pragmatic Language Assessment for Children (KOPLAC) was used for pragmatic language assessment. It consists of three sub-domains: communication regulation, story rules \& inference information, and metalanguage awareness. Results: As expected, pragmatic language abilities improve with age. Every matching of age groups and every sub-domain compared by age group showed statistically significant differences. In particular, communication regulation and indirect expressions were domains that showed greater score gaps between age groups. In general, the correlations between pragmatic language abilities and vocabulary abilities were significant. Conclusion: This study confirms that children show developmental growth in pragmatic language. In further studies, a greater selection of the population should be involved, and other assessment tools could be used to get more information about pragmatic language development.
\end{abstract}

Keywords: Pragmatic language, Pragmatic language development, Pragmatic language assessment
화용론은 음운론, 의미론, 구문론, 형태론 등과 더불어 언어학적 분석단위로서 언어의 기능이나 사용에 관하여 연구하는 영역이다. 다시 말하면, 화용론은 화자와 청자가 사회적인 상호작용 상황에 서 언어를 사용하는 방법에 관하여 연구한다(Levinson, 1983). 화 용론의 개념을 구체화하기 위한 노력의 일환으로, 연구자들은 언 어 형식에 관한 지식과 실제 인간 관계에서 언어 지식을 사용하는 것을 구별하여 왔다(Abbeduto \& Short-Meyerson, 2002). 화용론 에서는 언어를 구성하는 형식 자체에 관심을 두는 것이 아니라, 이 형식을 실제 의사소통에서 의미 있게 사용하는 현상에 초점을 맞
추는 것이다. 언어의 하위 영역을 추상성의 연속체에 놓고 봤을 때, 화용론은 가장 덜 추상화된 영역이라 할 수 있겠다(Carnap, 1942).

화용능력은 언어를 통해서도 표현되지만, 언어 외적인 방법으로 도 표현되며, 이는 언어능력보다 앞서 습득된다(Bara, Bosco, \& Bucciarelli, 1999). 실제로 한 낱말조차 표현하지 못하는 아이들도 의사소통을 할 수 있다. 이는 비언어적인 방법으로 이루어지는 의 사소통, 즉 화용능력이 발휘된 결과인 것이다. 이러한 의미에서 언 어 이전 단계는 “순수한 화용론”이 발휘되는 시점이라 할 수 있겠 다(Stephens \& Matthews, 2014). 의사소통 발달의 초기에서부터 
출현하는 화용능력은 생득적인 것이며 매우 당연한 것으로 인식되 기 때문에 언어 발달에서 화용능력만 분리해 내는 것은 쉽지 않다. 정상적인 언어 발달 과정에서 낱말의 뜻을 이해하고 명료한 발음으 로 산출하는 과정은 다른 사람을 향한 의사 표현과 분리되어 일어 나지 않기 때문이다. 아이가 '까까 줘', '까까 아니야'라고 표현할 때, 말의 의미 및 음운 형식을 충분히 연습 한 후에 남을 향해 표현하는 것이 아니라, 자신의 의도를 언어 형식과 함께 사용하면서 의사소 통 하는 것이다. 이처럼 언어의 사용은 언어 형식에 대한 지식과 동 시에 발현된다.

화용 발달 연구는 초기 의사소통 의도의 출현이나 언어 이전 혹 은 언어 발달 초기의 의사소통 행동에 초점을 맞춰 왔다(Adams, 2002). 생후 6 개월 이전에 아기는 이미 엄마의 말과 낮선 사람의 말 을 구별할 수 있고, 긍정적인 말투와 부정적인 말투가 다르다는 것 을 알 수 있다(Stephens \& Matthews, 2014). 8-9개월에는 상호작용 에서의 주고 받는 규칙을 인식하게 되며, 12 개월 이전에 비언어적으 로 의사소통 기능을 표현할 수 있다. 14 개월에서 32 개월 사이에 낱 말을 표현하기 시작하고, 의사소통 행동도 폭발적으로 늘어난다 (Snow, Pan, Imbens-Bailey, \& Herman, 1996). 표현언어가 나타난 이후로 끊임 없는 대화를 통해 말 차례 지키기나 존대 표현 등과 같 은 화용 규칙이 새롭게 적용되고, 실수를 수정하면서 안정화된다.

대화에서의 주고 받기는 3 세 정도에 형성되기 시작하고, 의사소 통에서의 교환성이 일찍 출현하는 것에 비해, 주고 받는 말을 지속 적으로 연습하면서 주제 유지 능력이 안정화 된다. 또한 상당 부분 의 의사소통 기능은 3-4세에 나타나지만, 약속하기나 설득하기, 공 손한 표현과 같은 좀 더 높은 수준의 기능은 9세 이후에 완전하게 습득된다(Snow et al., 1996). 존대 표현의 경우, 4-5세에 출현하기 시작하여 9 세 정도에 완성된다고 하는데, 특히 5 세 전후의 아동의 경우 덜 친숙한 사람에게는 존대 표현을 하고, 친숙한 사람에게는 존대 표현을 하지 않아도 된다는 점을 인식할 수 있다(Baroni \& Axia, 1989; Tsuji \& Doherty, 2014). 그리고 6-7세 경부터 상위화용 능력, 즉 의사소통 규칙을 반영하여 설명할 수 있는 능력이 출현하 기 시작한다고 한다(Collins, Lockton, \& Adams, 2014; KarmiloffSmith, 1986).

특정 주제로 이야기를 산출하는 능력은 5세 무렵에 나타난다. 3-4세는 산출된 이야기나 대화를 통해 정보를, 4-6세는 간접적인 의미도 추론하기 시작한다(Bernicot, Laval, \& Chaminaud, 2007). 이야기 산출 능력의 발달과 함께 인지적 확장이 언어 발달 전반에 영향을 미치면서 만 4 세 이후 참조나 추론, 응집성과 같은 상위화 용능력도 나타나기 시작한다. 7 세까지 담화 표지를 사용하는 능력 이 다양해지면서, 이야기 맥락에서의 화용능력이 확장되고(Ad- $\mathrm{ams}, 2002)$, 특정 사건이나 사물, 인물 등을 지칭하는 참조 표현이 동시에 발달한다(Davies, Andrés-Roqueta, \& Norbury, 2016). 9-12 세는 응집 장치 사용이 증가하면서 참조 오류가 감소하며(Ripich \& Griffin, 1988), 관용어 습득은 17세까지도 지속된다고 한다(Spector, 1996).

화용능력의 발달은 다른 언어 영역의 발달과도 관련이 있다(Hong \& Kim, 2001). 특히 의미론의 측면에서 아동은 어휘를 습득하고 표 현하게 되면서 의사소통능력을 보다 활발하게 발휘하게 된다(Han, 2015). 또한 의사소통을 할 때 문법능력이나 다른 언어적 지식이 부 족해도 의미가 전달될 수 있지만 어휘능력이 낮으면 의미를 전달하 는데 어려움이 있다(as cited in Kim, 2006). 이처럼 기본적인 의사 소통을 위해 어휘는 중요하다고 할 수 있다. Han (2015)의 연구에 서도 어휘능력에 따라 취학 전 아동을 분류하여 화용능력을 살펴 봄으로써 어휘발달과 화용발달 사이의 연관성을 확인할 수 있었 다. 학령기 저학년 일반아동의 화용언어능력도 어휘능력이 낮은 아동들에 비해 높았으며, 어휘능력과 화용언어능력의 상관관계는 하위 영역에 따라차이가 있는 것으로 나타났다(Jeon, 2016).

언어평가는 표준화된 공식적인 도구를 사용하거나, 비공식적인 관찰 혹은 체크리스트 등의 활용으로 이루어진다. 공식 및 비공식적 인 평가의 결과로 아동의 언어능력이 또래와 어떤 차이를 보이는지 를 확인하고, 어려움이 발견된 경우, 평가 결과를 토대로 중재를 위 한 계획을 세운다. 하지만 화용언어능력에 대한 기존의 연구는 특정 화용능력이 출현한 시기 정보를 제공할 뿐이고, 연구 자체가 충분하 지 않기 때문에 표준화된 공식검사를 개발하는 데 한계가 있다. 뿐 만 아니라 개인의 의사소통 스타일이 화용능력을 수행하는 데 영향 을 미쳐, 현재로서는 이러한 다양성을 어떻게 평가해야 할지에 대한 합의가 아직 이루어지지 않고 있는 상태이다(Adams, 2002).

지금까지 아동을 대상으로 개발된 화용언어 평가는 부모 및 양 육자를 통한 설문지나 체크리스트 형식의 간접평가와 직접평가 또 는 관찰평가로 나뉜다(Song, Yang, Kim \& Yim, 2016). 간접평가는 아동을 잘 아는 부모나 주양육자가 직접 검사에서 드러나지 않는 다양한 상황에서의 화용상의 특성을 보고한다. 따라서 시시각각 변화할 수 있는 아동의 상태 변화에 덜 영향을 받고, 구조화된 검 사 상황에서 이끌어내기 어렵거나 발생빈도가 낮은 화용 특성에 대한 정보를 얻을 수 있다는 장점을 지닌다(Bishop, 1998). 간접평 가의 대표적인 도구로는 Children's Communication Checklist-2 (CCC-2; Bishop, 2003)이 있다. CCC-2는 화용언어의 결함 여부를 확인하고자 개발된 $\mathrm{CCC}$ 의 수정 버전으로, 검사 대상자를 정기적 으로 만나는 사람이나 부모 혹은 양육자가 작성하는 체크리스트 이다. 이 도구는 기존의 화용언어능력 외에 기본적인 언어능력을 
Seungha Song, et al. • Pragmatic Language Development of 4- to 10-Year-Old Typically Developing Children CMMMUNICATION SCIINCES \& DISORDERS

선별하는 기능을 추가하고, 사회적 상호작용 점수(Social-Interaction Deviance Composite, SIDC)를 제공함으로써 화용언어능력 에 어려움을 보이는 대상자를 변별하기 위한 타당도와 신뢰도가 입증되었다(Norbury, Nash, Baird, \& Bishop, 2004). 그러나 부모나 주양육자 등을 통한 보고 형식의 평가는 아동의 화용능력을 있는 그대로 측정하기 어려운 면이 있다.

지금까지 개발된 직접평가는 화용능력을 평가하는 것과 상위화 용능력을 평가하는 것으로 나뉜다. 화용능력 평가에는 자연스러운 맥락에서 특정 화용 기능의 산출을 어떻게 하는지, 혹은 제한된 상 황에서의 화용 수행이 어떤지에 대해 평가한다. 영어 사용자를 대 상으로 개발된 도구의 예로 Test of Pragmatic Language-2 (TOPL-2; Phelps-Terasaki \& Phelps-Gunn, 2007)가 있고, Clinical Evaluation of Language Fundamentals-5th Edition (CELF-5; Wiig, Semel, \& Secord, 2013)과 같이 종합검사의 하위 검사로 이루어지는 평가 도 있다. 메타화용인식(metapragmatic awareness, MPA) 평가는 특정 상황 맥락에 적용되는 화용 규칙을 이해하는 지에 대해 평가 하는 것이다(Baroni \& Axia, 1989; Lockton, Adams, \& Collins, 2016). 지금까지 메타화용인식에 관한 평가는 거의 이루어지지 않고 있다. 하지만 메타화용인식에 결함이 있는 경우는 아동의 언어능력에 대 한 고려와 함께 이 인식을 높이는 것을 반드시 염두에 둬야 하기 때 문에 중재에 큰 시사점을 제공한다고 할 수 있다(Collins et al., 2014). 최근 출간된 Receptive, Expressive, and Social Communication Assessment-Elementary (RESCA-E; Hamaguchi \& Ross-Swain, 2016) 는 초등학교 아동을 대상으로 언어 형식과 사용을 아우르는 종합 검사의 형태를 띠면서, 의사소통 상황에서 직접 관찰할 수 있는 화 용능력과 메타화용인식을 동시에 평가하며, 직접검사를 보완하기 위해 부모나주양육자 등을 통한 간접검사까지도 포함하고 있다.

정신장애 진단 및 통계편람 5판(Diagnostic \& Statistical Manual 5th Edition, DSM-5)에서 사회(화용) 의사소통 장애(social (pragmatic) communication disorder, SCD)가 새롭게 정의되면서 화용 평가의 필요성은 더욱 커지고 있는 실정이다. 최근 국내에서도 화 용언어검사 도구에 대한 연구 및 화용평가의 필요성에 대한 논의 가 진행되고 있다. Lee (2010)의 연구에서는 국외 화용언어 평가도 구를 분석하였으며, Oh, Lee와 Kim (2012)은 '아동 화용능력 체크 리스트'문항을 개발하고, 학령전기 일반아동과 의사소통장애 아 동을 대상으로 예비연구를 실시한 바 있다. 하지만 지금까지 화용 언어 발달에 대한 국내 연구는 많지 않으며, 아동의 화용언어능력 을 평가할 도구도 제한적이다. 앞으로는 학령기 아동도 포함하는 화용능력 연구가 필요하고, 복잡한 화용능력을 세분화해서 분석 하는 연구도 요청된다.
따라서 본 연구는 대화나 이야기 화면을 보면서 화용적인 적절성 을 판단하고 수정하는 시청각적 담화 과제를 통해 4-10세 일반아동 의 화용언어 발달 특성을 파악하고, 어휘능력과 화용언어능력의 상관도를 분석하고자 하였다. 이에 따른 연구 문제는 아래와 같다.

1. 일반아동은 연령에 따라 전반적인 화용언어 및 하위과제 수행 력에 유의한 차이를 보이는가?

2. 일반아동의 화용언어능력은 어휘능력과 유의한 상관관계를 보이는가?

\section{연구방법}

\section{연구대상}

본 연구는 서울 및 수도권 지역에 거주하는 만 4-10세의 일반아 동 41 명을 대상으로 하였다. 참여 아동은 모두 (1) 주양육자 또는 초 등학교 및 유치원 담임 교사에 의해 인지 및 신체 능력이 정상 범주 에 속한다고 보고되었고, (2) 한국어를 모국어로 사용하는 단일언 어 사용자이며, (3) 수용 및 표현어휘력검사(Receptive and Expressive Vocabulary Test, REVT; Kim, Hong, \& Kim, 2009) 결과 표현 및 수용어휘력 점수가 모두 정상 범주(-1 SD 이상)에 속하는 아동 으로 선정하였다.

참여 아동은 학령전기(만 4-6세), 저학년(만 7-8세), 중학년(만 9-10세), 총 3개의 집단으로 분류하였다. 이들의 생활연령과 REVT 결과는 Table 1과 같다. 4-6세 학령전기 집단은 총 16 명이었고, 생활 연령 평균은 $70.8(\mathrm{SD}=7.94)$ 개월이었으며, 수용 및 표현어휘력 평 균은 각각 $91.5(\mathrm{SD}=16.15)$ 점, $90.1(\mathrm{SD}=14.49)$ 점이었다. 7-8세 저 학년 집단은 총 15 명이었고, 생활연령 평균은 $91(\mathrm{SD}=5.65)$ 개월이 며, 어휘력 평균은 수용이 $116.7(\mathrm{SD}=19.05)$ 점, 표현이 $114.8(\mathrm{SD}=$ 18.58)점이었다. 9-10세 중학년 집단은 총 10 명이었고, 생활연령 평 균 $120.0(\mathrm{SD}=8.32)$ 개월, 수용 및 표현어휘력 평균은 각각 155.4 $(\mathrm{SD}=27.81)$ 점, $169.4(\mathrm{SD}=26.53)$ 점이었다.

본 연구는 이화여자대학교 생명윤리위원회로부터 인간대상연구 에 대한 심의를 받아 진행되었다(IRB No. 96-6). 모든 연구 참여자의

Table 1. Participants' characteristics

\begin{tabular}{lccc}
\hline & \multicolumn{3}{c}{ Age group } \\
\cline { 2 - 4 } & $4-6$ yr $(\mathrm{N}=16)$ & $7-8$ yr $(\mathrm{N}=15)$ & $9-10 \mathrm{yr}(\mathrm{N}=10)$ \\
\hline Age $(\mathrm{mo})$ & $70.8(7.94)$ & $91.0(5.65)$ & $120.0(8.32)$ \\
REVT-receptive & $91.5(16.15)$ & $116.7(19.05)$ & $155.4(27.81)$ \\
REVT-expressive & $90.1(14.49)$ & $114.8(18.58)$ & $169.4(26.53)$ \\
\hline
\end{tabular}

Values are presented as mean (SD).

REVT= Receptive \& Expressive Vocabulary Test (Kim, Hong, \& Kim, 2009). 
부모님은 연구에 대한 정보를 제공받고, 연구 참여에 동의하였다.

\section{실험 과제 및 절차}

학령전기 및 학령기 아동의 화용언어능력을 분석하기 위하여 다 양한 예비연구가 진행된 한국아동화용검사(Korean Pragmatic Language Assessment for Children, KOPLAC; Kim, in press)를 실 험 과제로 실시하였다(Kim \& Song, 2016; Kim, Song, Lee, Kim, \& Yoo, 2016). 본 도구는 DSM-5에 근거한 화용능력 평가를 목적으 로, 의사소통 조율, 이야기 규칙 및 정보 추론, 그리고 상위언어 이 렇게 3 개의 하위 영역으로 구성되어 있다. DSM-5에서는 사회 의사 소통과 화용의 요소를 모두 포함하여 사회(화용) 의사소통 장애를 정의하고 있다(American Psychiatric Association, 2013). 이에 의사 소통 조율 영역은 사회 의사소통에 초점을 맞춘 하위 영역이고, 상 위언어 영역은 화용에 초점을 맞추어 문항들을 설정하였다. 여기 서 상위언어는 포괄적인 개념이라기보다는 화용과 관련이 깊은 협 의적인 것으로, 특히 간접표현과 참조, 반어 및 비유의 화용적 이해 및 표현에 활용되는 개념이다.

의사소통 조율은 다시 대화 상대자와 상황맥락 조율로 나뉘고, 상위언어는 간접표현과 참조, 그리고 반어 및 비유로 구성 되었으며, 하위 영역에 따른 특성은 Table 2와같다.

의사소통 조율능력은 의사소통이 이루어지는 전체 맥락을 고려 하여 상황에 맞게 말을 조정하는 것으로, 대화 상대자에 따라 말의 형태를 조절하는 것과 상황 문맥에 따라 목소리의 크기를 조절하 거나 말의 내용을 조율하는 능력을 평가한다. 이야기 규칙 및 정보 추론능력은 짧은 이야기를 듣고, 그 이야기에서 제시한 사실 이해 를 바탕으로 등장 인물의 정서, 원인과 결과, 문제해결 및 불충분하 거나 빠진 정보를 추론하여 전체적인 이야기 맥락을 이해하는 능 력을 평가한다. 마지막으로 상위언어에서는 간접적인 표현이나 참
조적 표현, 그리고 반어 및 비유 표현을 이해하거나 사용하는 데 필 요한 상위언어 인식능력을 평가한다.

KOPLAC 문항은 특정 의사소통 상황을 설정하여, 상황에 대한 배경설명과 인물들의 대화로 구성되어있다. 모든 문항에 해당하는 그림을 제작하고, 각 문항의 스크립트를 녹음하여, 컴퓨터에서 구 동되는 프로그램으로 제작되었다(Appendix 1). 아동은 이러한 시 청각적 담화 과제를 접한 뒤, 검사자가 제시하는 문제를 듣고 반응 하게 된다. 모든 문항은 아동이 원하면 2번까지 들을 수 있고, 검사 자의 질문도 3 번까지 반복해서 제시할 수 있다. 8 명을 대상으로 문 항타당도(5점 척도)를 알아보기 위한 예비연구(Jeon, 2016; Hwang, 2016)에서는 의사소통 조율 과제 4.56, 이야기 규칙 및 정보추론 과 제 4.84 , 상위언어인식 과제 4.66 의 문항타당도를 보였다.

의사소통 조율 능력은 연습문제를 제외하고 총 38 문항으로 구 성되어 있는데, 그 중 대화상대자는 29문항, 상황문맥은 9문항으로 구성되었으며, 각각 2 개의 false 문항을 포함하고 있다. 의사소통 조 율 능력에서는 각 문항에서 제시하는 상황에 대한 화용적 적절성 을 판단하는 판단과제와 수정과제로 구성되어 있다. 각 문항의 그 림을 보면서 해당 스크립트를 들은 후, 검사자는 아동에게 “마지막 에 00 가 한 말이 상황에 맞는 것 같아, 좀 이상한 것 같아?”라고 질 문하고(판단과제), 아동이 부적절하다는 판단을 하면, “그럼 어떻 게 고치면 좋을까?”라고 수정을 요구한다(수정과제). 대화 상대자 에 따른 의사소통 조율 능력은 존대 및 하대 표현을 적절히 조율하 는 능력으로 호칭 조율과 체언부 조율, 그리고 용언부 조율로 나누 어 구성하였다. 호칭 조율은 대화상대자를 부르는 말로, 화자의 입 장에서 대화상대자를 부를 때 어휘 및 조사를 통해 적절한 호칭을 사용하는 능력이다. 체언부 조율은 ‘밥-진지’나 ‘말-말씀'과 같이 대 화상대자에 따라 어휘를 통해, 용언부 조율은 '자다-주무시다'와 같은 어휘나 선어말어미 '-시' 등을 통해 존대 및 하대 표현을 조율

Table 2. Sub-domains of KOPLAC

\begin{tabular}{|c|c|c|c|}
\hline \multirow{2}{*}{ Sub-domain } & \multirow{2}{*}{ Purposes of the tasks } & \multicolumn{2}{|c|}{ Number of items } \\
\hline & & Preschool & School \\
\hline \multicolumn{4}{|l|}{ Communication regulations } \\
\hline Communication partners & To test the ability to change grammatical forms according to conversational partners & \multicolumn{2}{|c|}{29} \\
\hline Situational context & To test the ability to change tones of voice or regulate expressions proper to conversational context & \multicolumn{2}{|c|}{9} \\
\hline $\begin{array}{l}\text { Story rules \& information } \\
\text { inferences }\end{array}$ & $\begin{array}{l}\text { To test the ability to understand the facts in a story, to find out absent information and to guess emotions or situations } \\
\text { through the story }\end{array}$ & 18 & 20 \\
\hline \multicolumn{4}{|l|}{ Meta-language } \\
\hline Indirect expressions & To test understanding of indirect expression and the ability to deal with the situation & \multicolumn{2}{|c|}{12} \\
\hline References & To test the ability to sum up various information and find out the referential target & \multicolumn{2}{|c|}{9} \\
\hline Irony \& metaphor & To test the meta-linguistic ability to understand ironical \& metaphoric expressions & 0 & 14 \\
\hline Total & & 77 & 93 \\
\hline
\end{tabular}

KOPLAC $=$ Korean Pragmatic Language Assessment for Children (Kim, in press). 
Seungha Song, et al. • Pragmatic Language Development of 4- to 10-Year-Old Typically Developing Children CMMMUNICATION SCIINCES \& DISORDERS

하는 능력이다.

이야기 규칙 및 정보추론은 4 컷으로 구성된 공통 이야기에, 학령 전기의 경우 4 컷 이야기 2 개를 추가로 실시하고, 학령기의 경우 5 컷 이야기와 6컷 이야기 각각 하나씩을 추가로 실시하였다. 각 이야기 를 듣고, 전체 그림을 한 번에 보면서 이야기 다시 말하기를 실시한 뒤, 6-7문항의 이해검사를 실시하였다. 이해검사는 사실이해, 인과 관계에 따른 추론, 불충분한 정보 인식, 빠진 정보 추론, 그리고 문 제해결 문항으로 구성되며, 학령전기의 경우 총 18 문항, 학령기는 20 문항을 실시하였다.

상위언어는 간접표현 12 문항, 참조 9 문항, 반어 및 비유 14 문항으 로, 총 35 문항으로 구성되어 있다. 간접표현은 간접표현을 듣고 화 자의 의도를 표현하는 의도이해 문항과 간접표현을 하는 화자의 상 대자라면 이런 표현을 듣고 어떻게 할지에 대한 대처문항으로 나뉜 다. 일례로, 지훈이가 민수네 놀러 갔는데, 민수한테는 갖고 싶었던 스티커가 많은 걸 보고 “민수야, 너 스티커 엄청 많다”라고 표현했 다. 의도이해 문항은 “지훈이의 말은 무슨 뜻일까요?”이고, 대처문 항은 “만약 네가 민수라면 어떻게 할래?”이다. 참조는 여러 정보를 통합하여 지시하는 대상을 찾아내거나 그러한 대상을 찾을 수 있 도록 설명하는 것으로, 이해 및 표현문항으로 나뉜다. 이해문항은 특정 상황에서 일련의 정보를 주고 해당하는 지시 대상을 찾아내 도록 구성하였고, 표현문항은 특정 대상을 찾을 수 있도록 여러 정 보를 표현할 수 있도록 하였다. 반어 및 비유는 원래의 의도와 반대 로 표현하거나 유사한 것에 빗대어 표현하는 것이다. 이 영역은 학 령기에 본격적으로 발달하기 시작하여 17 세까지도 지속된다고 한 다(Spector, 1996). 따라서 본 연구에서는 학령전기 아동을 대상으 로 반어 및 비유에 대한 검사를 실시하지 않았다. 반어는 총 10 문 항, 비유는 2 문항으로 구성되었다. 반어의 경우, 전반 5 문항은 억양 없는 목소리로, 후반 5 문항은 억양 있는 목소리로 제공되었다. 억양 없음과 있음에 각각 2 개씩 총 4 개의 false 문항이 포함되어 있다.

$\mathrm{KOPLAC}$ 은 문헌 연구를 거쳐 문항을 개발한 후, 시청각적 자료 를 개발하였다. 15 명의 유치원생 및 초등학생을 대상으로 1 차 예비 검사를 실시하여 시청각적 자료를 수정하였다. 그 후 서울 및 수도 권에 소재한 만 4 세에서 10 세 사이의 아동 115 명을 대상으로 2 차 예비 검사를 실시하였다. 그 결과로 영역별 문항의 난이도를 조절 하여, 문항 수 및 난이도에 따른 문항 배치를 조절하였고, 시청각적 자료 수정을 진행하였다.

\section{신뢰도}

언어병리학 석사과정에 있는 연구자 2 명이 전체 데이터의 $20 \%$ 에 해당하는 자료를 임의로 선정하여 신뢰도를 산출하였다. 전체 항
목에서 일치한 항목 수의 비율을 측정한 결과, 신뢰도는 $94.5 \%$ 로 나타났다.

\section{자료 분석 및 처리}

$\mathrm{KOPLAC}$ 을 실시하여 나타난 아동의 반응에 대해 다음과 같이 채점하였다. 의사소통 조율과 상위언어 간접표현의 판단과제, 이야 기 문항, 상위언어 참조, 그리고 상위언어 반어 및 비유는 오반응 0, 정반응 1 점으로 채점하였으며, 의사소통 조율과 상위언어 간접표 현의 수정 및 대처과제는 오반응 0 , 정반응 1 또는 2 점 체계로 채점 하였다. 의사소통 조율과 상위언어 간접표현에서 정반응은 답변의 사회적 수용 가능성을 기준으로 가중치를 두어 채점하였다. 즉, 문 맥에 맞으면서 사회적으로 수용 가능한 방식의 화용 표현은 2점, 문 맥에는 맞지만 사회적인 수용 가능성이 상대적으로 떨어지는 화용 표현은 1 점으로 채점하였다.

화용언어 과제에 따라 세 연령 집단의 수행 능력의 차이가 통계 적으로 유의한 지 살펴보기 위하여, 이원혼합분산분석(two-way mixed ANOVA)을 실시하였다. 또한 어휘력과 화용언어능력의 상 관관계를 알아보기 위해, Pearson 적률상관계수(Pearson productmoment correlation coefficients)를 산출하였다.

\section{연구결과}

본 연구는 KOPLAC을 활용하여 일반아동을 연령집단으로 나 뉘 화용언어능력을 평가하였고, 연령 집단별 KOPLAC 결과는 Table 3과 같다. KOPLAC의 모든 하위 영역 점수는 연령이 높아지면 서 평균 수행이 증가하였다(Figure 1). 의사소통 조율과 상위언어 중 간접표현은 4-6세 집단에서 평균 50\% 미만의 정확도를 보였고,

Table 3. Statistical results of KOPLAC

\begin{tabular}{llll}
\hline & \multicolumn{3}{c}{ Accuracy (\%) } \\
\cline { 2 - 4 } Sub-domain & $\begin{array}{c}4-6 \mathrm{yr} \\
(\mathrm{N}=16)\end{array}$ & $\begin{array}{c}7-8 \mathrm{yr} \\
(\mathrm{N}=15)\end{array}$ & $\begin{array}{c}9-10 \mathrm{yr} \\
(\mathrm{N}=10)\end{array}$ \\
\hline Communication regulations & & & \\
$\quad$ Communication partners & $40.4(17.41)$ & $64.2(9.57)$ & $77.5(9.72)$ \\
$\quad$ Situational context & $26.1(11.9)$ & $47.6(20.90)$ & $66.6(16.75)$ \\
Story rules \& information inferences & $76.3(10.24)$ & $82.6(11.63)$ & $92.0(5.87)$ \\
Meta-language & & & \\
Indirect expressions & $46.8(23.44)$ & $65.5(20.50)$ & $87.9(8.44)$ \\
References & $84.7(14.55)$ & $94.0(8.26)$ & $97.7(4.68)$ \\
Irony \& metaphor & $\mathrm{NT}$ & $74.7(39.39)$ & $95.7(6.02)$ \\
\hline
\end{tabular}

Values are presented as mean (SD).

KOPLAC = Korean Pragmatic Language Assessment for Children (Kim, in press); NT= not tested. 
연령이 증가함에 따라 집단별로 정확도가 평균 $20 \%$ 씩 높아지는 것 으로 나타났다. 이에 비해 이야기와 상위언어 중 참조에서는 4-6세 집단의 정확도가 이미 평균 $70 \%$ 이상이었고, 이에 따라 연령 집단 별 증가 폭이 $6 \%$ 정도였다. 상위언어 중 반어 및 비유는 학령전기 집단에는 실시하지 않았고, 7-8세 집단에서 평균 $74.7 \%$ 의 정확도 를 보였으며, 9-10세 집단은 평균 정확도가 $95.7 \%$ 에 달하였다.

Table 4에 나타난 바와 같이 ANOVA를 실시한 결과, 연령집단

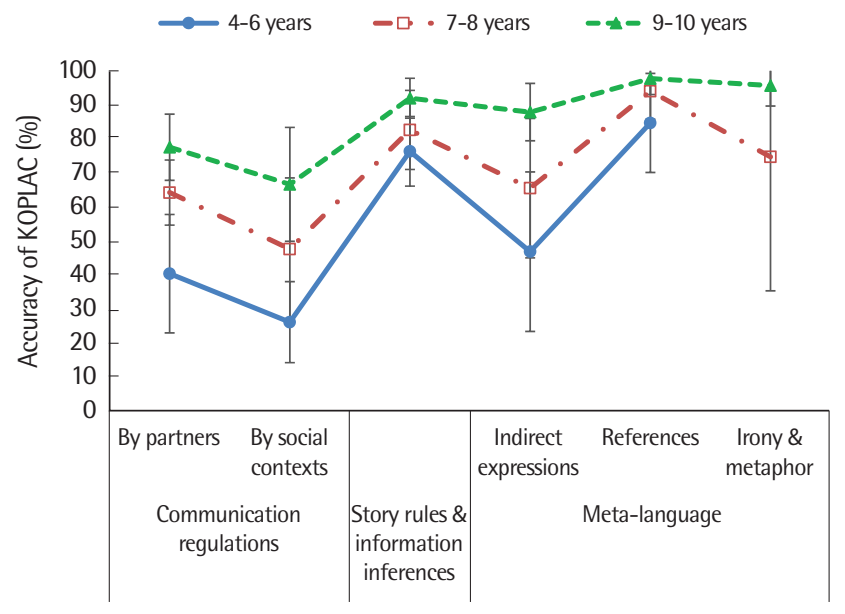

Figure 1. Korean Pragmatic Language Assessment for Children (KOPLAC) results.

Table 4. ANOVA results by groups

\begin{tabular}{|c|c|c|c|c|c|c|}
\hline & & & & & -hoc ana & \\
\hline & $\Gamma$ & $p$-value & I) & & & $p$-value \\
\hline Group & 89.478 & $<.0001$ & .825 & $4-6 \mathrm{yr}$ & $7-8 \mathrm{yr}$ & $<.0001$ \\
\hline & & & & $7-8 \mathrm{yr}$ & $9-10 \mathrm{yr}$ & $<.0001$ \\
\hline & & & & $4-6 \mathrm{yr}$ & $9-10 \mathrm{yr}$ & $<.0001$ \\
\hline
\end{tabular}

간 주효과가 통계적으로 유의하였다 $\left(F_{(2,38)}=89.478, p<.0001\right) .4-6$ 세 집단의 평균은 45.76, 7-8세 집단은 71.49, 그리고 9-10세 집단은 86.28로, 연령이 증가함에 따라 화용언어능력은 유의하게 증가하 였다. 사후분석 결과, 각 집단의 모든 대응별 비교에서도 유의한 차 이를 보였다.

화용언어 과제의 주효과도 통계적으로 유의하였다 $\left(F_{(7,38)}=42.476\right.$, $p<.0001)$. 사후분석 결과, 상위언어 반어 및 비유는 의사소통 조율 의 두 영역과 상위언어 간접표현에서 유의한 차이를 나타내지 않았 지만, 그 밖의 하위과제 간 대응별 비교에서는 모두 통계적으로 유 의한 차이를 나타냈다(Appendix 2).

과제와 집단 간 상호작용도 통계적으로 유의하였다 $\left(F_{(14,38)}=13.495\right.$, $p<.0001$ ) (Table 5). Figure 2와 같이, 대화상대자에 따른 의사소통

Table 5. ANOVA results by KOPLAC and group

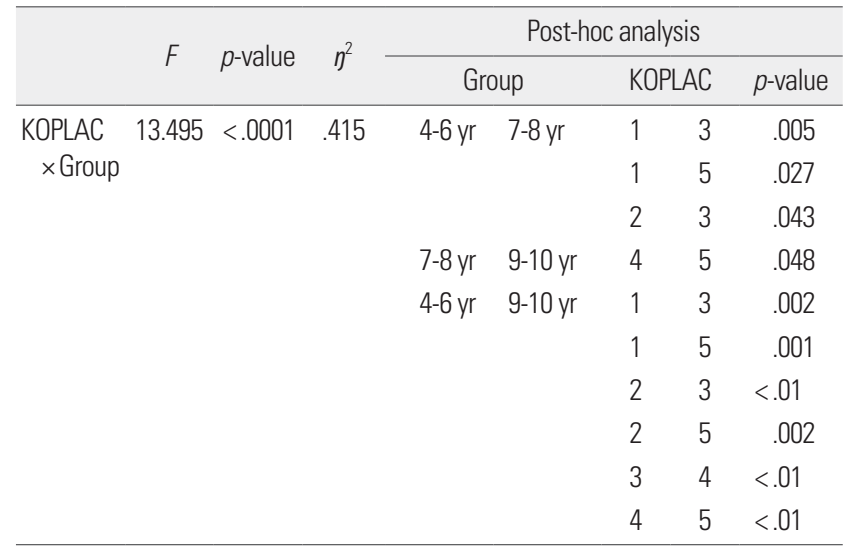

KOPLAC $=$ Korean Pragmatic Language Assessment for Children (Kim, in press). KOPLAC sub-domain $1=$ communication regulation by communication partners; $2=$ communication regulation by situational context; $3=$ story rules $\&$ information inference; $4=$ meta-language of indirect speech; $5=$ meta-language of references; $6=$ meta-language of irony $\&$ metaphor.
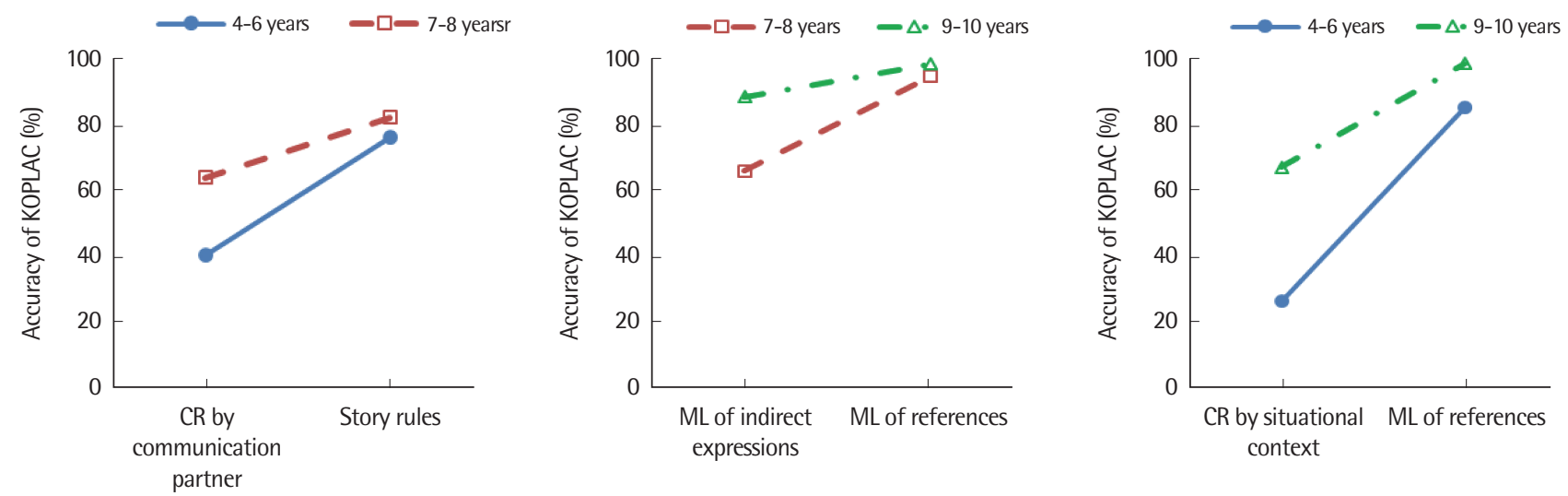

Figure 2. KOPLAC $\times$ group interaction graph.

KOPLAC = Korean Pragmatic Language Assessment for Children (Kim, in press); $C R=$ communication regulation; $M L=$ meta-language. 
Seungha Song, et al. • Pragmatic Language Development of 4- to 10-Year-Old Typically Developing Children COMmuniCATION SCIENCES\& Disorders

Table 6. Correlations between KOPAC sub-domains and REVT

\begin{tabular}{|c|c|c|c|c|c|c|}
\hline & \multicolumn{2}{|c|}{ Communication regulations } & \multirow{2}{*}{$\begin{array}{l}\text { Story rules \& informa- } \\
\text { tion inferences }\end{array}$} & \multicolumn{3}{|c|}{ Meta-language } \\
\hline & Communication partners & Social contexts & & Indirect expressions & References & Irony \& metaphor \\
\hline Age & $.756^{* *}$ & $.676^{* *}$ & $.581^{* *}$ & $.700 * *$ & $.417^{* *}$ & $.751^{* *}$ \\
\hline REVT-receptive & $.645^{* *}$ & $.718^{* *}$ & $.420^{* *}$ & $.559 * *$ & $.390^{*}$ & $.577^{* *}$ \\
\hline REVT-expressive & $.714^{* *}$ & $.717^{* *}$ & $.470^{* *}$ & $.656^{* *}$ & $.486^{* *}$ & $.593^{* *}$ \\
\hline
\end{tabular}

KOPLAC= Korean Pragmatic Language Assessment for Children (Kim, in press); REVT= Receptive \& Expressive Vocabulary Test (Kim, Hong, \& Kim, 2009).

${ }^{*} p<.05,{ }^{* *} p<.01$.

조율 과제에서 학령전기 아동과 저학년 아동의 수행 차이는 이야 기 규칙 과제에서의 차이보다 유의하게 큰 것으로 나타났다 $(p<.01)$. 상위언어 참조 과제에서 저학년 아동과 중학년 아동의 수행점수 차이는 상위언어 간접표현 과제에서의 차이보다 유의하게 작았다 ( $p<.05)$. 또한 상황맥락에 따른 의사소통 조율 과제에서 학령전기 아동과 중학년 아동의 수행 차이는 상위언어 참조 과제에서의 차 이보다 유의하게 큰 것으로 나타났다 $(p<.01)$. 그 밖에 유의하게 나 타난 상호작용 결과는 Appendix 3에 추가하였다.

KOPLAC의 하위 영역과 연구 참여자의 연령, 그리고 수용 및 표 현어휘능력 사이의 Pearson 상관계수를 산출한 결과는 Table 6과 같다. 연령은 KOPLAC의 모든 하위 영역에 대해 유의수준 .01에서 모두 유의한 상관관계를 보였으며, 그 범위는 .417-.756이었다. 수용 어휘력(REVT-R)은 KOPLAC의 하위 영역에 대해 유의수준 .01에 서 대부분 유의한 상관관계를 나타냈으며, 범위는 .390-.718이었다. 표현어휘력(REVT-E)과 KOPLAC 하위 영역의 상관관계도 유의수 준 .01에서 .470-.717로 유의하게 나타났다. 특히 의사소통 조율의 두 영역인 대화상대자와 상황문맥은 연령과 어휘력에 대해 모두 .60 이상의 강한 상관관계를 보였다. 이에 비해 이야기 및 참조는 .3-.5로 보통 정도의 상관관계를 나타냈다. 연령집단 간 평균 차가 컸던 의사소통 조율의 두 영역과 상위언어(간접표현)에서는 상대 적으로 강한 상관관계를 보였고, 집단 간 평균 차가 다소 적었던 이 야기와 상위언어(참조)에서는 상대적으로 낮은 상관관계를 보였다.

\section{논의 및 결론}

본 연구는 만 4 세에서 10 세 아동을 대상으로 화용언어능력의 발 달 특성을 알아보고자 하였다. 대상자는 학령전기 4-6세, 저학년 7-8세, 중학년 9-10세의 세 그룹으로 나누고, 의사소통 조율, 이야 기, 그리고 상위언어로 구성된 화용언어검사 KOPLAC을 실시하였 다. 그 결과, 화용언어능력은 연령이 증가함에 따라 성취도가 높은 것으로 나타났다. 모든 하위 영역은 통계적으로 유의한 차이를 보 였으며, 사후분석 결과, 특히 이야기 과제와 상위언어 참조 과제는
모든 하위과제들과 유의한 차이를 나타냈다. 연령집단과 화용능력 하위과제 간 상호작용 효과도 통계적으로 유의하게 나타났다. 대체 로 학령전기와 저학년 집단, 그리고 학령전기와 중학년 집단에서 과제 간에 유의한 상호작용을 보였다. 어휘력과 KOPLAC 하위 영 역 간 상관관계를 살펴 본 결과, 전반적으로 39 이상의 상관관계를 보였으며, 특히 의사소통 조율의 두 하위 영역은 .6 이상의 강한 상 관관계를 나타냈다.

KOPLAC의 하위 영역 중 의사소통 조율은 다른 영역에 비해 아 동의 정확도가 상대적으로 낮게 나타났다. 의사소통 조율은 대화 상대자에 따른 조율과 상황문맥에 따른 조율로 다시 나뉘는데, 대 화 상대자에 따른 조율능력은 어휘나 문법 형태소를 통해 상대에 맞게 존대와 하대를 표현하는 능력이고, 상황문맥에 따른 조율능 력은 공적 혹은 사적 상황에 맞게 말의 내용이나 목소리의 크기 등 을 조절하는 능력을 평가한다. 학령전기 아동의 경우, 이 두 영역에 서 $50 \%$ 미만의 정확도를 보였으며, 학령기에 이르러서야 $50 \%$ 이상 의 정확도를 보이기 시작하고, 만 9 세에 이르러서도 $80 \%$ 미만의 정 확도를 나타냈다. 이는 존대 표현이 4-5세에 출현하기 시작해서 9세 정도에 완성된다는 선행 연구와 일치하는 결과이다(Baroni \& Axia, 1989; Tsuji \& Doherty, 2014). 또한 대부분의 의사소통 행동은 3-4 세에 나타나지만, 좀 더 높은 수준의 화행은 9세 이후에 완전하게 습득된다는 Snow 등(1996)의 연구 결과도 일치한다.

상위언어 간접표현은 상대적으로 의사소통 조율에 비해 약간 높 은 정확도를 보였지만, 학령전기에는 정확도가 $50 \%$ 미만이었고, 9-10세에 이르러서야 $80 \%$ 정도의 정확도를 보였다는 측면에서 의 사소통 조율과 유사한 특성을 나타냈다. 간접표현은 간접적으로 표현된 화자의 의도를 파악하는 능력으로, 이에 대한 상위언어 인 식, 즉 메타화용인식 능력을 평가한다. Bernicot 등(2007)에 의하 면, 초등학교 저학년 시기에 메타화용인식은 정교화와 복잡성에 있어 큰 전환을 맞이한다고 한다. 즉 만 6세에 이르면, 화자의 행동 에 대한 메타화용인식에서 화자의 의도에 대한 메타화용인식으로 전환되면서, 적절한 요구 표현이나 관용적 표현에 대한 이해가 발 달한다는 것이다. 본 연구 결과도 간접표현 능력에 대한 이해는 학 
령기에 이르러서야 $50 \%$ 이상의 정확도를 나타냈다.

반어 및 비유와 같은 관용어에 대한 이해는 메타화용인식의 정 교화 및 복잡성의 일면으로, 학령기에 본격적으로 발달하기 시작 하여 17세까지도 지속된다(Spector, 1996). 이와 같은 이유에서 본 연구는 반어 및 비유는 학령기만을 대상으로 실시하였고, 그 결과 저학년부터 $70 \%$ 전후의 정확도를 보이기 시작하여, 9-10세에 이르 러 천정효과를 보이고 있다. 비록 9-10세에 이르러 상당 수준의 정 확도를 보였다 할지라도 반어 및 비유의 습득이 안정되었다고 단정 하기는 이르다. 관용적 표현의 경우, 구어에서 사용하는 표현에는 한계가 있고, 연령이 증가함에 따라 읽기 활동을 통해 그 능력이 더 욱 발달될 가능성이 높기 때문이다.

이야기 및 상위언어 참조 능력은 연령에 따른 유의한 발달 양상 을 보였지만, 연령 그룹 간 차이가 상대적으로 작은 편이었다. Bernicot 등(2007)에 의하면, 대략 3-4세 경부터 이야기를 통해 정보를 추론하는 능력이 나타나기 시작하고, 4-6세 사이에 대화 및 이야기 에서 간접적인 의미 추론이 가능해진다고 한다. 또한 7세까지 담화 표지를 사용하는 능력이 다양해지면서, 사물이나 인물을 지칭하 는 참조 표현이 동시에 발달하는데, 단순 맥락에서 명확한 참조 표 현은 대략 6세 정도면 성인 수준의 능력을 보인다고 한다(Davies et al., 2016). 본 연구에서도 이야기 및 참조 능력은 7-8세 집단에서 이 미 70\% 이상의 정확도를 보이고 있으며, 9-10세에 이르러서는 평균 $90 \%$ 이상의 정확도를 나타낸다. 이야기 과제의 경우, 표현하는 능 력이 아니라 이야기에서 제시하는 사실 이해를 바탕으로 정서나 인 과적 추론, 혹은 불충분한 정보에 대한 추론 능력을 평가하는 형식 이므로, 4-6세 사이에 이야기에서의 간접적인 의미 추론이 가능해 진다는 선행연구처럼 학령전기부터 안정적으로 습득되는 것으로 나타났다. 참조 능력 또한 상대적으로 일찍 습득되는 영역으로, 본 연구에서도 4-6세 사이에 평균 84.7\%의 정확도를 나타냈다.

어휘능력과 상관관계 분석 결과에서 수용이나 표현어휘력은 화 용언어평가의 하위과제에 대해 대부분 .39 이상의 상관관계를 나 타냈다. 특히 의사소통 조율은 두 하위과제 모두에서 .6 이상의 강 한 상관관계를 나타냈다. 이는 상황에 따른 조절 영역에서 일반아 동과 어휘발달지체 아동 간에 유의한 차이가 있는 것으로 나타난 Han (2015)의 연구와 일치한다. Jeon (2016)의 연구결과에서도 이 야기나 상위언어와는 달리 의사소통 조율능력이 어휘능력과 높은 상관관계를 나타냈으며, 이에 대해 의사소통 조율과제가 대화상대 자에 따라 말의 형태를 변화시켜야 하는 문항들로 구성되어 있기 때문이라고 분석했다. 한편 본 연구에서 이야기와 상위언어 참조는 어휘능력과 상대적으로 낮은 상관관계를 보였다. 이는 이야기 평가 와 상위언어 과제가 아동에게 쉬운 어휘로 구성되어 어휘력과 상관
관계가 낮은 것으로 분석한 Jeon (2016)의 연구 결과와도 일치한다. 따라서 이러한 현상들이 장애군에서도 나타나는지를 알아보기 위 해 후속연구가 필요하겠다.

본 연구에서는 총 41 명의 아동을 대상으로 하였고, 특히 9-10세 아동의 수가 다른 연령 집단에 비해 상대적으로 적은 바, 후속 연구 에서는 충분한 수의 대상자를 연구에 포함시킬 필요가 있다. 또한 화용능력과 어휘능력의 상관도에 대한 타당한 논의를 위해 후속연 구가 계속되어야 한다. 마지막으로 화용언어에 어려움을 보이는 임 상군과의 비교 연구뿐 아니라 다양한 화용언어 평가 방식과 그 결 과를 비교 분석하여 화용언어 발달 특성에 대한 다양한 논의를 이 끌어내는 것이 필요하겠다.

\section{REFERENCES}

Abbeduto, L., \& Short-Meyerson, K. (2002). Linguistic influences on social interaction. In H. Goldstein et al. (Eds.), Promoting social communication: children and youth with developmental disabilities (pp. 27-54). Baltimore, MD: Paul H. Brooks Publishers.

Adams, C. (2002). Practitioner review: the assessment of language pragmatics. Journal of Child Psychology and Psychiatry, 43, 973-987.

American Psychiatric Association (2013). Diagnostic and statistical manual of mental disorders (5th ed.). Washington, DC: American Psychiatric Publishing.

Bara, B. G., Bosco, F. M., \& Bucciarelli, M. (1999). Developmental pragmatics in normal and abnormal children. Brain and Language, 68, 507-528.

Baroni, M. R., \& Axia, G. (1989). Children's meta-pragmatic abilities and the identification of polite and impolite requests. First Language, 9, 285-297.

Bernicot, J., Laval, V., \& Chaminaud, S. (2007). Nonliteral language forms in children: In what order are they acquired in pragmatics and metapragmatics? Journal of Pragmatics, 39, 2115-2132.

Bishop, D. V. (1998). Development of the Children's Communication Checklist (CCC): A method for assessing qualitative aspects of communicative impairment in children. Journal of Child Psychology and Psychiatry, 39, 879891.

Bishop, D. V. (2003). The Children's Communication Checklist: CCC-2. London: Harcourt Assessment.

Carnap, R. (1942). Introduction to semantics. Cambridge, MA: Harvard University Press.

Collins, A., Lockton, E., \& Adams, C. (2014). Metapragmatic explicitation ability in children with typical language development: development and 
Seungha Song, et al. • Pragmatic Language Development of 4- to 10-Year-Old Typically Developing Children COMmuniCATION SCIENCES\& DISORDERS

validation of a novel clinical assessment. Journal of Communication Disorders, 52, 31-43.

Davies, C., Andrés-Roqueta, C., \& Norbury, C. F. (2016). Referring expressions and structural language abilities in children with specific language impairment: a pragmatic tolerance account. Journal of Experimental Child Psychology, 144, 98-113.

Hamaguchi, P., \& Ross-Swain, D. (2016). Receptive, Expressive and Social Communication Assessment - Elementary (RESCA-E). Novato, CA: Academic Therapy Publications.

Han, S. (2015). Analysis of the pragmatic competence of preschool children at risk for vocabulary developmental delay with CPLC (Master's thesis). Ewah Womans University, Seoul, Korea.

Hong, G. H., \& Kim, Y. T. (2001). A longitudinal study of the acquisition of communicative intentions. Korean Journal of Communication Disorders, 6, 17-39.

Hwang, H. (2016). Indirect speech acts comprehension of high-functioning autistic children according to the presence of facial expression (Masters' thesis). Ewha Womans University, Seoul, Korea.

Jeon, H. (2016). Pragmatic competence of school-aged children in accordance to their vocabulary development and socioeconomic status (Masters' thesis). Ewha Womans University, Seoul, Korea.

Karmiloff-Smith, A. (1986). From meta- processes to conscious access: evidence from children's metalinguistic and repair data. Cognition, 23, 95-147.

Kim, B. J. (2006). A study on vocabulary instruction to improve English communicative competence: focus on English verbs. English Language \& Literature Teaching, 12, 131-158.

Kim, Y. T. (in press). Korean Pragmatic Language Assessment for Children (KOPLAC). Seoul: Paradise Welfare Foundation.

Kim, Y. T., \& Song, S. (2016). Preliminary study on developing Korean Pragmatic Language Assessment for Children (KOPLAC) based on DSM-5. Proceedings of 2016 Annual Conference of the Korean Academy of SpeechLanguage Pathology and Audiology, Seoul, Korea.

Kim, Y. T., Hong, K. H., \& Kim, K. H. (2009). Content and reliability analyses of the receptive and expressive vocabulary test (REVT). Korean Journal of Communication Disorders, 14, 34-45.

Kim, Y. T., Song, S., Lee, S., Kim, S., \& Yoo, H. (2016). Pragmatic language abilities of Korean children with high-functioning autism. Proceedings of 2016 Annual Conference of the Korean Academy of Speech-Language Pa- thology and Audiology, Seoul, Korea.

Lee, E. J. (2010). Analysis of abroad pragmatic language measures and assessing instruments. Journal of Speech and Hearing Disorders, 19, 109-132.

Levinson, S. C. (1983). Pragmatics. Cambridge: Cambridge University Press. Lockton, E., Adams, C., \& Collins, A. (2016). Do children with social communication disorder have explicit knowledge of pragmatic rules they break? A comparison of conversational pragmatic ability and metapragmatic awareness. International Journal of Language \& Communication Disorders, 51, $508-517$

Norbury, C. F., Nash, M., Baird, G., \& Bishop, D. V. (2004). Using a parental checklist to identify diagnostic groups in children with communication impairment: a validation of the Children's Communication Checklist-2. International Journal of Language \& Communication Disorders, 39, 345364.

Oh, S., Lee, E. J., \& Kim, Y. T. (2012). Preliminary study on developing test items of children's pragmatic language checklist. Journal of Speech \& Hearing Disorders, 21, 111-135.

Phelps-Terasaki, D., \& Phelps-Gunn, T. (2007). Test of Pragmatic Language second edition (TOPL-2). Austin, TX: Pro-Ed.

Ripich, D. N., \& Griffith, P. L. (1988). Narrative abilities of children with learning disabilities and nondisabled children: story structure, cohesion, and propositions. Journal of Learning Disabilities, 21, 165-173.

Snow, C. E., Pan, B. A., Imbens-Bailey, A., \& Herman, J. (1996). Learning how to say what one means: a longitudinal study of children's speech act use. Social Development, 5, 56-84.

Song, S., Yang, Y., Kim, Y. T., \& Yim, D. (2016). A meta-analysis of Children's Communication Checklist (CCC) for children \& adolescents with pragmatic language impairment. Communication Sciences \& Disorders, 21, 436-450.

Spector, C. C. (1996). Children's comprehension of idioms in the context of humor. Language, Speech, and Hearing Services in Schools, 27, 307-313.

Stephens, G., \& Matthews, D. (2014). The communicative infant from 0-18 months. Pragmatic Development in First Language Acquisition, 10, 13-36.

Tsuji, H., \& Doherty, M. J. (2014). Early development of metalinguistic awareness in Japanese: evidence from pragmatic and phonological aspects of language. First Language, 34, 273-290.

Wiig, E. H., Semel, E., \& Secord, W. A. (2013). Clinical Evaluation of Language Fundamentals - fifth edition (CELF-5). Bloomington, MN: Pearson 
Appendix 1. Examples of the Korean Pragmatic Language Assessment for Children (KOPLAC)

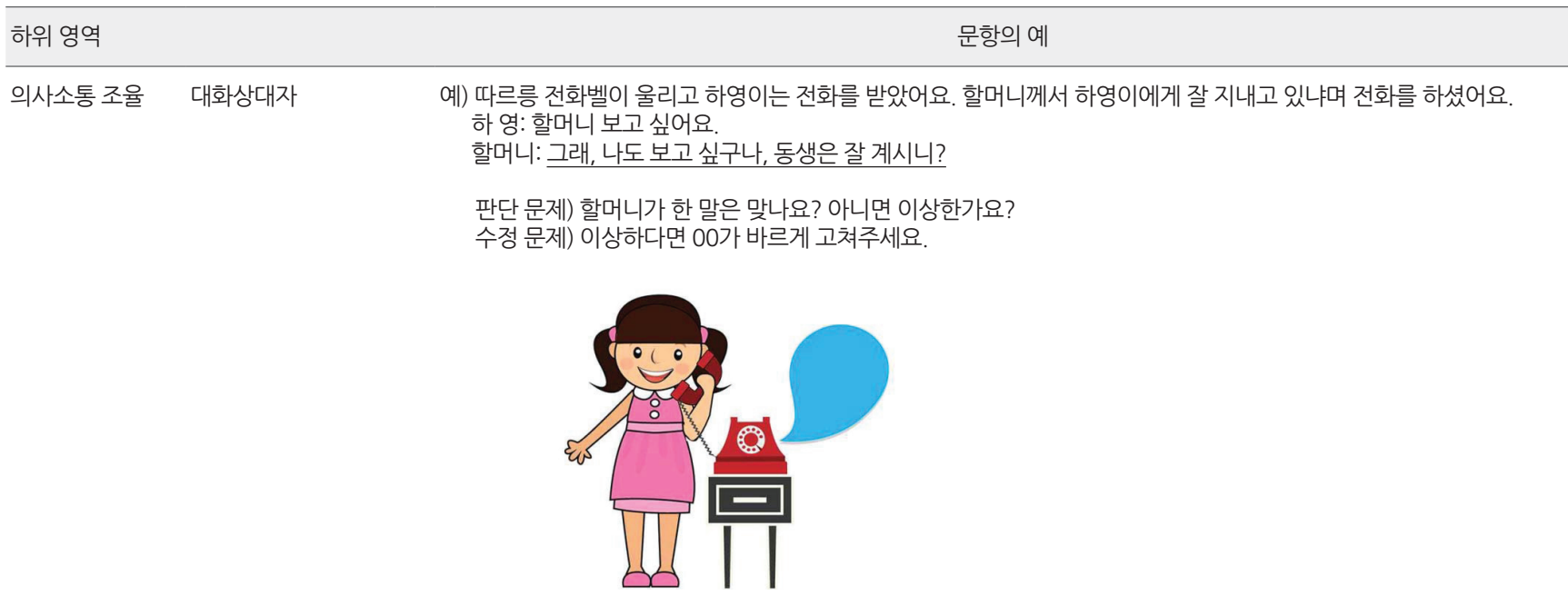

상황맥락

예) 하영이는 엄마와 슈퍼에 가기 위해 엘리베이터를 탔어요. 엘리베이터 안에는 사람이 많이 있었어요. "엄마, 사람이 너무 많아요. 저 사람들 다 내렸으면 좋겠어요"

판단 문제) 하영이는 지금 상황에 맞게 말했나요? 아니면 이상한가요?

수정 문제) 이상하다면 00 가 바르게 고쳐주세요.

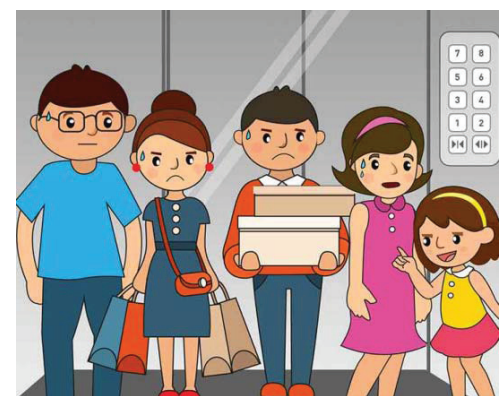

1컷: 지우는 샛별이네 집에서 종이 접기를 하고 있었어요.

2컷: 샛별이는 빨간색 종이배를 만들고 화장실에 갔어요. 그런데 지우는 샛별이가 없는 사이에 그 종이배를 만지고 놀다 가 망가뜨려버렸어요

3컷: 샛별이는 종이배가 망가진 것을 보았어요.

4컷: 지우는 샛별이에게 새 종이배를 주면서 사과했고 샛별이는 기분이 나아졌어요.

빠진 정보 추론 문제) 지우는 샛별이에게 뭐라고 말했을까요?

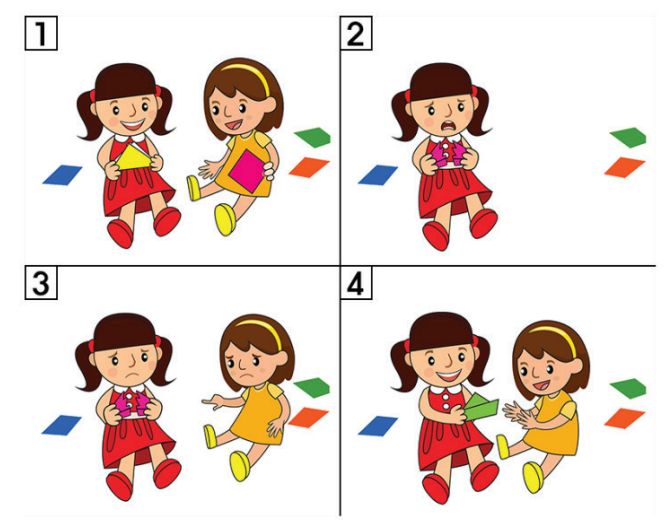


Seungha Song, et al. • Pragmatic Language Development of 4- to 10-Year-Old Typically Developing Children

Appendix 1. Continued

\begin{tabular}{|c|c|c|}
\hline 하위 영역 & & 문항의 예 \\
\hline 상위언어 & 간접표현 & $\begin{array}{l}\text { 예) 무더운 여름이었어요. 아빠와 민수는 공원에서 신나게 공놀이를 하고 쉬고 있었어요. } \\
\text { 아빠: 아이고 덥다! } \\
\text { 민수: 아, 이럴 때 아이스크림이 딱인데! } \\
\text { 의도이해 문제) 민수의 말은 무슨 뜻일까요? } \\
\text { 대처 문제) 00가 아빠라면 어떻게 할래요?. }\end{array}$ \\
\hline
\end{tabular}

참조

이해 문제) 장난감 가게에 가서 오늘 생일 파티에 가서 친구들과 함께 가지고 놀 주사위 게임을 샀어요. 그림에서 지원이 가 누구인지 짚어보세요.

표현 문제) 그림에 보이는 친구를 선생님이 찾을 수 있도록 설명해주세요.

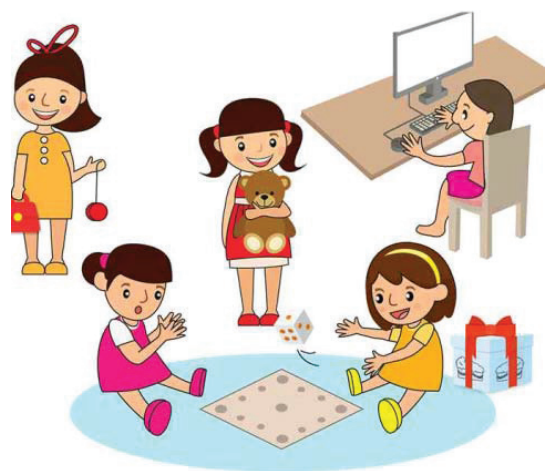

반어 및 비유

예) 수환이는 친구와 야구를 하고 놀다가 엄마의 화분을 깨뜨리고 말았어요. 그러자 친구는 "수환아, 너네 엄마가 보면 참 좋아하시겠다!" 하고 말했어요.

친구가 말한 것은 무슨 뜻일까요

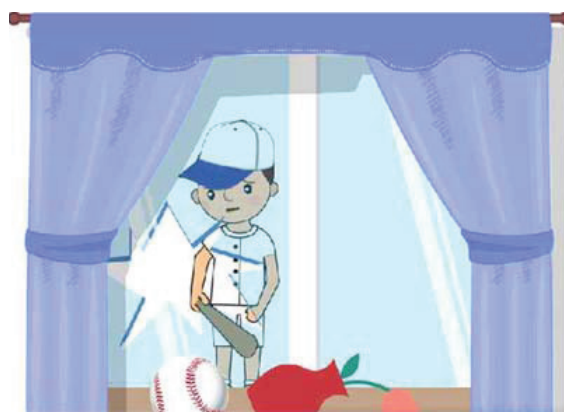


Appendix 2. ANOVA results by sub-domains of KOPLAC

\begin{tabular}{|c|c|c|c|c|c|c|}
\hline \multirow{3}{*}{ KOPLAC } & \multirow{3}{*}{$\begin{array}{c}F_{(7,38)} \\
42.476\end{array}$} & \multirow{3}{*}{$\begin{array}{c}p \text {-value } \\
<.0001\end{array}$} & \multirow{3}{*}{$\begin{array}{c}\eta^{2} \\
0.528\end{array}$} & \multicolumn{3}{|c|}{ Post-hoc analysis } \\
\hline & & & & \multicolumn{2}{|c|}{ Sub-domain } & \multirow{2}{*}{$\begin{array}{r}p \text {-value } \\
.004^{*}\end{array}$} \\
\hline & & & & 1 & 2 & \\
\hline & & & & & 3 & $.000^{* *}$ \\
\hline & & & & & 4 & 1.000 \\
\hline & & & & & 5 & $.000^{* *}$ \\
\hline & & & & & 6 & 1.000 \\
\hline & & & & 2 & 3 & $.000^{* *}$ \\
\hline & & & & & 4 & $.000^{* *}$ \\
\hline & & & & & 5 & $.000^{* *}$ \\
\hline & & & & & 6 & 1.000 \\
\hline & & & & 3 & 4 & $.001^{*}$ \\
\hline & & & & & 5 & $.009^{*}$ \\
\hline & & & & & 6 & $.000^{* *}$ \\
\hline & & & & 4 & 5 & $.000^{* *}$ \\
\hline & & & & & 6 & 1.000 \\
\hline & & & & 5 & 6 & $.000^{* *}$ \\
\hline
\end{tabular}

Sub-domain $1=$ communication regulation by communication partners; $2=$ communication regulation by situational context; $3=$ story rules \& information inference; $4=$ metalanguage of indirect speech; $5=$ meta-language of references; $6=$ meta-language of irony $\&$ metaphor.

${ }^{*} p<.01,{ }^{* *} p<.001$. 
Seungha Song, et al. • Pragmatic Language Development of 4- to 10-Year-Old Typically Developing Children COMMUNICATION SCIENCES\& DISORDERS

Appendix 3. KOPLAC $\times$ group interaction graph
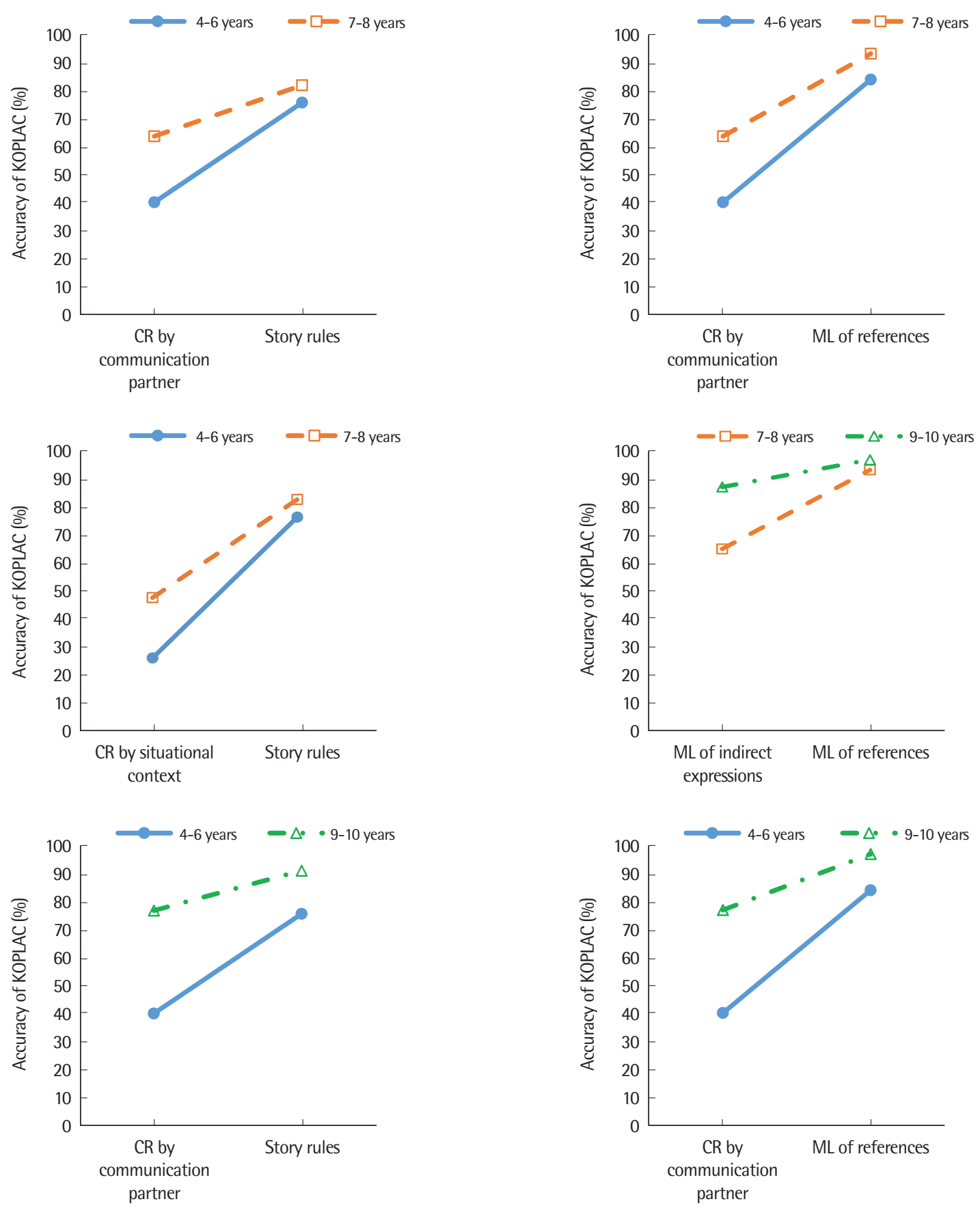

(Continued to the next page) 
Appendix 3. Continued
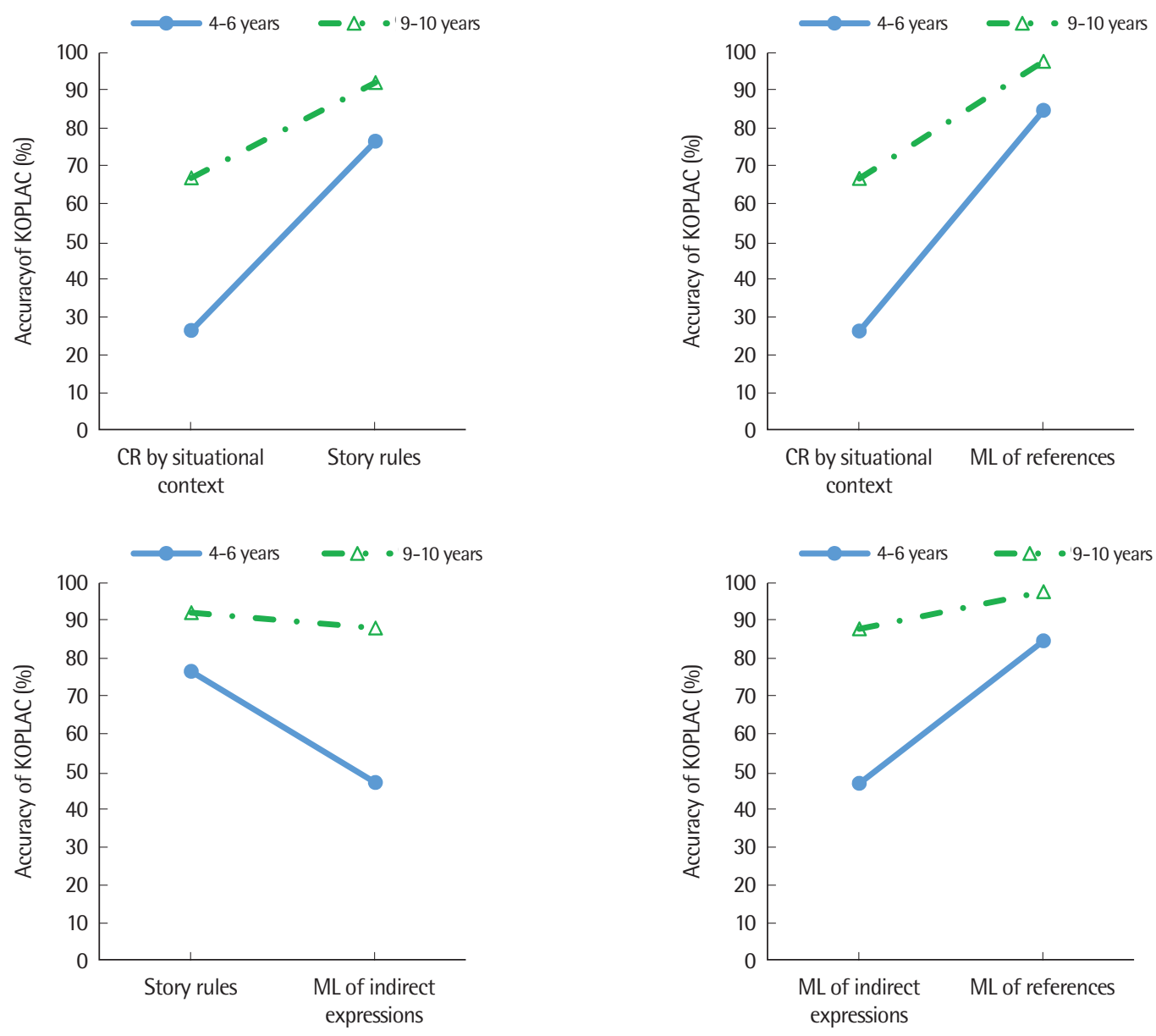

KOPLAC $=$ Korean Pragmatic Language Assessment for Children; $\mathrm{CR}=$ communication regulation; $\mathrm{ML}=$ meta-language . 
Seungha Song, et al. • Pragmatic Language Development of 4- to 10-Year-Old Typically Developing Children COMMUNICATION SCIINCES\& DIIORDERS

\section{국문초록}

\section{시청각적 담화 과제를 활용한 4-10세 아동의 화용언어 발달 및 어휘능력과의 상관도 연구}

송승하 · 김영태 · 이수정 · 김정아

이화여자대학교 대학원 언어병리학과

배경 및 목적: 아동은 사회적인 상호작용 속에서 언어를 사용하는 화용능력을 기르게 된다. 이러한 화용능력은 의미론적 발달이나 전 반적인 언어습득과도 상관이 높다고 알려져 있다. 그러나 우리나라에서는 평가도구의 제한으로 인해 화용능력에 대한 세부적인 연구 가 매우 부족하다. 이에 본 연구에서는 대화나 이야기 화면을 보면서 화용적인 적절성을 판단하고 수정하는 시청각적 담화 과제를 통해 4-10세 일반아동의 화용언어 발달 및 어휘능력과의 상관도를 분석하고자 하였다. 방법: 본 연구에서는 학령전기, 저학년, 중학년 41명 의 아동을 대상으로 한국아동화용언어검사(KOPLAC)를 통해 의사소통 조율 과제, 이야기 규칙 및 정보추론 과제, 상위언어인식 과제 를 실시하였다. 화용언어 하위과제에 따라 세 연령집단이 어떠한 차이를 나타내는지를 알아보기 위해 이원혼합분산분석을 실시하였 고, 어휘력과 화용언어능력의 상관도도 분석하였다. 결과: 화용언어능력은 연령이 증가함에 따라 유의하게 높아졌다. 모든 연령 집단 간, 그리고 하위 영역에 따른 연령 집단 간에서 모두 통계적으로 유의하게 나타났다. 특히 의사소통 조율 및 간접표현에서 연령 집단 간 성취도 차이가 컸다. 또한, 화용능력은 하위 영역 간 차이가 있기는 하지만, 연령뿐 아니라 수용 및 표현어휘력과도 유의한 상관도를 보 였다. 논의 및 결론: 연령이 증가함에 따라 화용언어능력은 향상되지만 하위 영역간에는 발달적 차이가 있음을 시사해 준다.

핵심어: 화용언어, 화용언어 발달, 화용언어평가

본 연구는 2016년 대한민국 교육부와 한국연구재단의 지원을 받아 수행된 연구임(NRF-2015S1A5A2A01009816).

\section{참고문헌}

김부자(2006). 의사소통 능력을 높여주는 어휘 지도에 대한 연구: 동사를 중심으로. 영어어문교육, 12, 131-158.

김영태(출판중). 한국 아동 화용언어능력 평가(KOPLAC). 서울: 파라다이스복지재단.

김영태, 송승하(2016). DSM-5에 기초한 아동언어장애 화용평가 프로그램 기초연구. 2016년 한국언어청각임상학회 학술대회.

김영태, 송승하, 이수정, 김소망, 유효연(2016). 한국 고기능자폐 아동의 화용언어능력. 2016년 한국언어청각임상학회 학술대회.

김영태, 홍경훈, 김경희(2009). 수용·표현 어휘력검사의 개발연구: 문항개발 및 신뢰도 분석을 중심으로. 언어청각장애연구, 14, 34-45.

송승하, 양윤희, 김영태, 임동선(2016). 아동 의사소통 체크리스트(CCC)를 활용한 화용언어장애아동의 의사소통능력 평가에 대한 메타분석. 언어

청각장애연구, 21, 436-450.

오소정, 이은주, 김영태(2012). 화용능력 체크리스트 문항 개발을 위한 예비 연구. 언어치료연구, 21, 111-135.

이은주(2010). 국외 화용언어 평가 도구 분석. 언어치료연구, 19, 109-132.

전혜인(2016). 어휘능력 및 사회경제적 지위에 따른 학령기 저학년 아동의 화용언어 특성. 이화여자대학교 석사학위논문.

한승희(2015). CPLC 체크리스트를 통한 어휘 발달 지연 위험군(at risk) 취학 전 아동의 화용 능력 분석. 이화여자대학교 석사학위논문.

홍경훈, 김영태(2001). 아동의 의사소통의도 습득에 대한 종단연구. 언어청각장애연구, 6, 17-39.

황현주(2016). 고기능 자폐 아동의 표정단서 유무에 따른 간접화행 이해. 이화여자대학교 석사학위논문. 